\title{
Use of Radon as Water Tracer at Juatuba Basin
}

\author{
Vinícius V. M. Ferreira ${ }^{1}$; Raquel L. M. Fonseca ${ }^{1}$; Zildete Rocha ${ }^{1}$; Amanda L.Oliveira ${ }^{1}$, Rubens M.Moreira ${ }^{1}$; \\ Nayron C. Lemos ${ }^{1}$; Cláudio J. Chagas ${ }^{1,2}$; Maria Angela B. C. Menezes ${ }^{1,2} \&$ Talita O. Santos ${ }^{2,3}$ \\ ${ }^{1}$ Development Center of Nuclear Technology, Belo Horizonte, Brazil. \\ ${ }^{2}$ Department of Nuclear Engineering - Federal University of Minas Gerais, Belo Horizonte, Brazil. \\ ${ }^{3}$ Department of Anatomy and Image - Federal University of Minas Gerais, Belo Horizonte, Brazil. \\ Correspondence: Vinícius Ferreira. CDTN/CNEN - Av. Antônio Carlos 6627, Campus UFMG - CEP 31270-901 \\ - Belo Horizonte - MG - Brazil. Email: vvmf@cdtn.br
}

Received: July 25, 2015

Accepted: August 23, 2015

Online Published: August 27, 2015

doi:10.5539/jgg.v7n3p49

URL: http://dx.doi.org/10.5539/jgg.v7n3p49

The research is financed by FAPEMIG - Foundation of Support Research - Minas Gerais State.

\begin{abstract}
For the last thirty years, several researches have been developed at Juatuba representative basin, located at the southeast region of Brazil, including the use of natural (tritium), fluorescent (rhodamine and fluorescein) and radioactive (technetium 99) tracers, to investigate and solve many hydrological problems. The goal of this paper is to present a research done at Juatuba basin, in order to look for discharge sections at the Fundão stream, using radon as natural tracer, to identify connections between surface and underground waters. The RAD7 equipment, which measures the concentration of radon in waters, was used to analyze water samples at different points, in three campaigns. After the identification of the sections were the radon had the biggest concentrations, a scan of two stretches was done, and the flows were measured with the help of the Flow Tracker device. The results showed a difference between the flows upstream and downstream, which associated to the peaks of the concentration of radon indicates the presence of a discharge zone.
\end{abstract}

Keywords: radon. hydrology, tracers, representative basin.

\section{Introduction}

The scientific and technological interest related to the use of tracers in hydrology arose from the vital need to monitor the water flows. Underground waters provide nutrients and other dissolved constituents for surface waters in some areas, which influences the geochemical cycle of most elements by the direct discharge of fresh underground water or by chemical reactions that occur during recirculation of surface water through the aquifer system. In the last years many hydrological problems reported by agriculture, catering, industry and housing areas, among others, could be solved with the help of the tracers technique. However, several processes related to the water distribution still require precise investigations such as those involving surface water, the water vapor in the atmosphere, subsurface water in unsaturated and saturated zones and the interrelationship between surface and underground water.

A tracer is any substance or particle (chemical or biological) that can be used to follow, in a punctual or continuous way, the behavior of a particular system or component, such as water flow in an open environment (surface hydrology) or underground (porous or fissural environment). Davis, Thompson, Bentley \& Stiles (1980) warn that a tracer must have the following characteristics: be nontoxic, inexpensive, provide unambiguous detection and quantification in minimum concentrations, move with water, do not disturb the system under study, be chemically stable, not be present in significant amounts in the watercourse under study and not be absorbed or filtrated by the solid medium through which the water moves.

The applicability of stable and radioactive isotopes as tracers to study the hydrological cycle has expanded in the last years, when a favorable instrumentation for measurements became available. Isotopes are elements chemically identical, with different mass number and that are naturally present in the hydrosphere / atmosphere (environmental isotopic tracers) or that can be intentionally added to water for specific investigations (artificial 
isotopic tracers). In many cases the processes studied include public drinking water, not being desirable the discharge of high levels of artificial substances in the systems - rivers, lakes, aquifers, oceans, among others (Giap, 2003). Thus, environmental isotopic tracers and are often recommended for applications in hydrology. As example of such tracers it is possible to mention (Singh \& Kumar, 2005):

- isotopic species of the water molecule $\left(\mathrm{H}_{2}{ }^{16} \mathrm{O}, \mathrm{HD}^{16} \mathrm{O}, \mathrm{H}_{2}{ }^{18} \mathrm{O}\right.$ e $\left.\mathrm{HT}^{16} \mathrm{O}\right)$ and ${ }^{14} \mathrm{~N}$ and ${ }^{15} \mathrm{~N}$ which are the primary sources of nitrogen in the atmosphere;

- isotopes produced by cosmic rays $\left({ }^{3} \mathrm{H},{ }^{10} \mathrm{Be},{ }^{14} \mathrm{C},{ }^{26} \mathrm{Al},{ }^{32} \mathrm{Si},{ }^{36} \mathrm{Cl},{ }^{39} \mathrm{Ar},{ }^{53} \mathrm{Mn},{ }^{59} \mathrm{Ni},{ }^{81} \mathrm{Kr}\right)$;

- radioactive pulses injected in water systems at tests of nuclear equipment, consisting of many long half-life isotopes such as ${ }^{3} \mathrm{H},{ }^{36} \mathrm{Cl},{ }^{85} \mathrm{Kr}$ and ${ }^{139} \mathrm{I}$;

- chloro-fluoro-carbon (CFC) introduced as propellants of aerosol bottles, as cleaning agents of refrigerators, solvents, etc.;

- ${ }^{238} \mathrm{U},{ }^{234} \mathrm{U},{ }^{232} \mathrm{Th}$ and its decay products, which are distributed over the crust of the planet.

Among the tracers used in various types of research, the water dynamics studies can be performed with the aid of isotopic species of this molecule. However, in some situations, the use of such species becomes unfeasible. As result, many alternative tracers are being developed and tested for this purpose, some of which have their physical and chemical behavior already reasoned.

At this scenario, the use of radon as a tracer is noteworthy. Radon has two isotopes applicable to the study of groundwater: ${ }^{222} \mathrm{Rn}$ (half-life $=3.8$ days) produced by the alpha decay of the ${ }^{226} \mathrm{Ra}$ in the series of ${ }^{238} \mathrm{U}$, and the ${ }^{220} \mathrm{Rn}$ (half-life $=56$ seconds) produced by the alpha decay of the ${ }^{232} \mathrm{Th}$ in the ${ }^{224} \mathrm{Ra}$ series (Figure 1). It is observed that the ${ }^{222} \mathrm{Rn}$ presents a greater half-life and that is the reason of its widely utilization as a water tracer (groundwater and surface) in streams and rivers, coastal and surface reservoirs, and to estimate the residence time of an aquifer (Silva et al, 2009), (Burnett \& Dulaiova, 2003). This occurs because the radon is chemically inert which makes possible to disregard biogeochemical reactions and facilitates its measurement. Furthermore, radon in groundwater is enriched when compared to surface waters (Burnett, Peterson, Moore \& Oliveira, 2008). This characteristic results from the fact that groundwater is in contact with mineral grains containing radio, and surface water is subject to turbulence generated by environmental factors, allowing the escape of radon.

Several studies carried out have used the ${ }^{222} \mathrm{Rn}$ as a tracer of groundwater, including:

- Giap (2003) determined the relationship between the concentration of radon in groundwater and surface water to estimate the groundwater infiltration rate in an aquifer based on the residence time of the water, and the distance between the surface water source and the observed wells;

- Chanyotha, Burnett, Taniguchi, Kritsananuwat \& Sriploy (2010) used the radon for surveys of radioisotopes and nutrients in the Chao Phraya River and at the Upper Gulf of Thailand, in order to find discharge areas of active groundwater to surface water, and estimate the biogeochemical significance of this discharge;

- Low (1996) investigated the dynamics of radon in the Chalk aquifer and evaluated its potential as a natural hydrological tracer;

- Freyer, Treutler, Dehnert \& Nestler (1997) found the infiltration rate in a nearby region close to the center of Torgau (Germany);

- Swarzenski (2007) studied the groundwater, including geochemical characterization of the underground environment, the definition of the transport kinetics of some substances, water-rock interactions and the determination of the geological age and the impact received by the groundwater flow. This was accomplished through the use of naturally occurring radionuclides of uranium and thorium series: $\mathrm{U}$, Th, $\mathrm{Ra}$ and $\mathrm{Rn}$. In this study the radon was emphasized as a tracer;

- Cook, Favreau, Dighton \& Tickell (2003) studied the natural groundwater influx to a tropical river in Australia with the help of environmental tracers, including radon. 


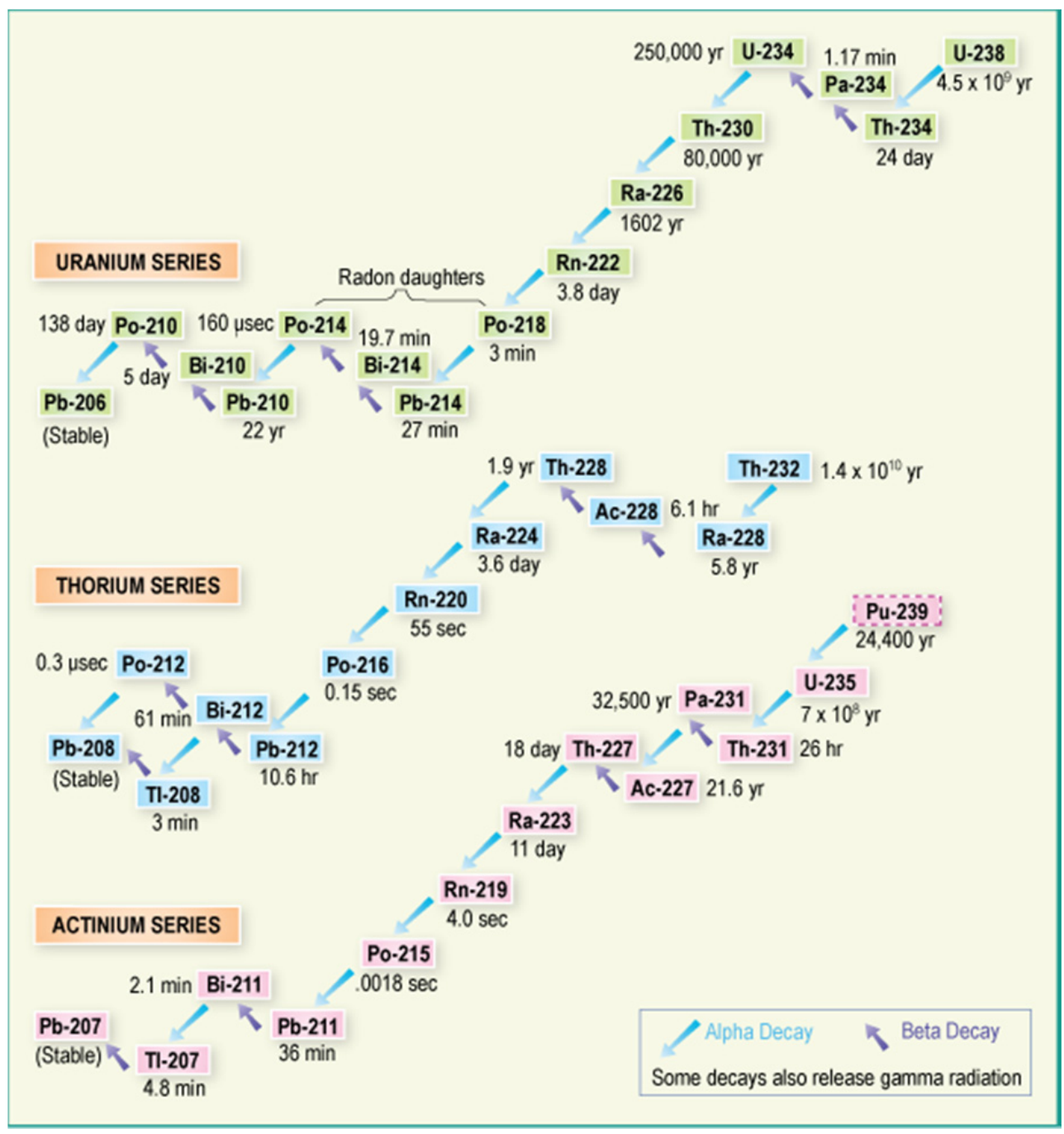

Figure 1. Natural radioactive series

The goal of this study is to investigate the relationship between surface and groundwater at Juatuba basin, aiming to find discharge sections with the help of radon, used as water tracer.

\section{Study Area}

The Juatuba basin (Figure 2) is located in the upper part of the São Francisco river, in Minas Gerais State southeast of Brazil. The Juatuba river is a left tributary of the Paraopeba river, which is a tributary of the São Francisco, and runs $3 \mathrm{~km}$ from the meeting of its main tributaries to the point where it flows into the Paraopeba. This watershed covers 442 square kilometers and is located $60 \mathrm{~km}$ from Belo Horizonte (capital of the State), covering part of the cities of Mateus Leme, Igarapé and Itaúna. The main streams that form the Juatuba river are the Serra Azul and Mateus Leme streams, which have a drainage area of 265 and 155 square kilometers respectively.

Downstream the Serra Azul stream there is an important reservoir that supplies water for Belo Horizonte and other close cities named Serra Azul reservoir. It covers parts of four cities: Mateus Leme, Juatuba, Igarapé and Itaúna and is located about $55 \mathrm{~km}$ far from Belo Horizonte. Its operation started in 1982 and today the system serves with treated water, about $10 \%$ of Belo Horizonte needs, being the third biggest one of the region. It forms, together with the Rio Manso and Vargem das Flores systems, the integrated system of Paraopeba river basin. It is valid to emphasize that currently this reservoir faces a serious situation since the absence of rains in the southeast of Brazil in the last months generated the worst hydrological crises in the history of the region. 


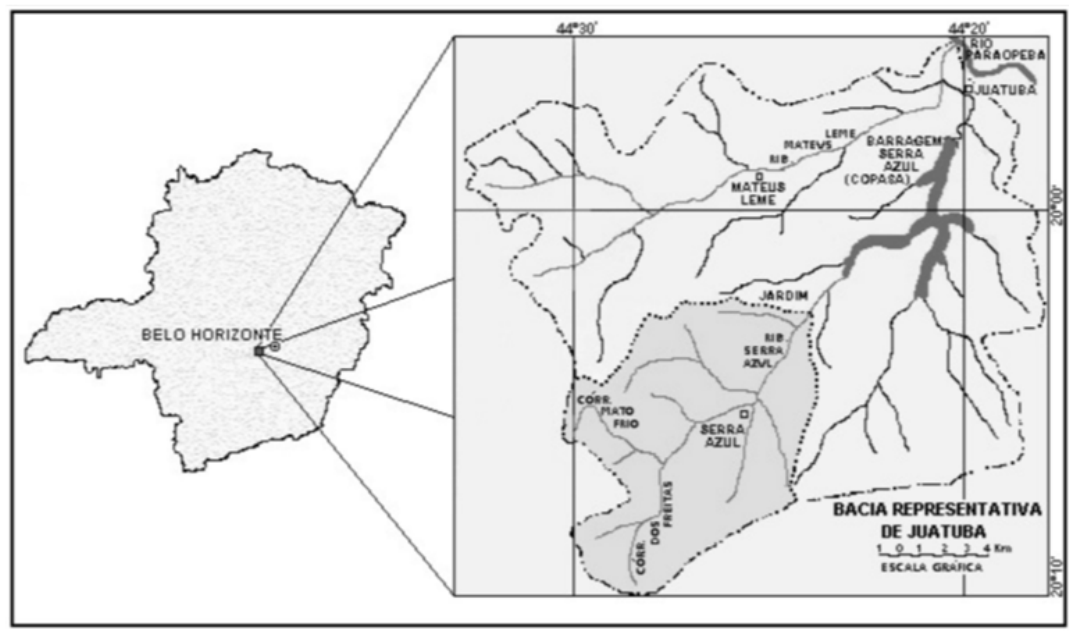

Figure 2. Juatuba basin: southeast region of Brazil

\section{Methodology}

At the first field visit (September/2014) some points (Figure 3) were randomized chosen at the Fundão stream (chosen as a pilot for this project), to collect water samples. The concentration of radon at these samples was determined with the help of the RAD7 equipment (DURRIDGE $\mathcal{C}, 2015)$. In this device a constant flow of water passes through a water/air exchanger, which distributes the radon present in running water to a circuit formed by the drying system and a continuous monitor. The RAD7 works in low internal humidity, no more than $6 \%$, what allows more accurate results and the possibility of reading small concentrations of radon.

The RAD7 has two ways to measure radon in water: GRAB mode for punctual measurements, and SCAN mode, which makes continuous measures. At this study the GRAB mode was used, since the goal was to find discharge sections along the stream. At GRAD mode, the RAD7 has three steps for its operation:

1. Drying - the device works to remove the water present in the system, in order not to damage the equipment. At this step the internal moisture of the device should be $\leq 6 \%$, which makes feasible the reading of the samples (Figure 4);

2. Analysis - for 30 minutes, the device performs 4 readings (Figure 5) and displays for each reading the standard deviation. After this, it calculates the average values for the sample;

3. Cleaning - after reading a sample, the RAD7 needs to be cleaned in an open circuit, to eliminate the radon which is in the system, for the next readings (Figure 6).

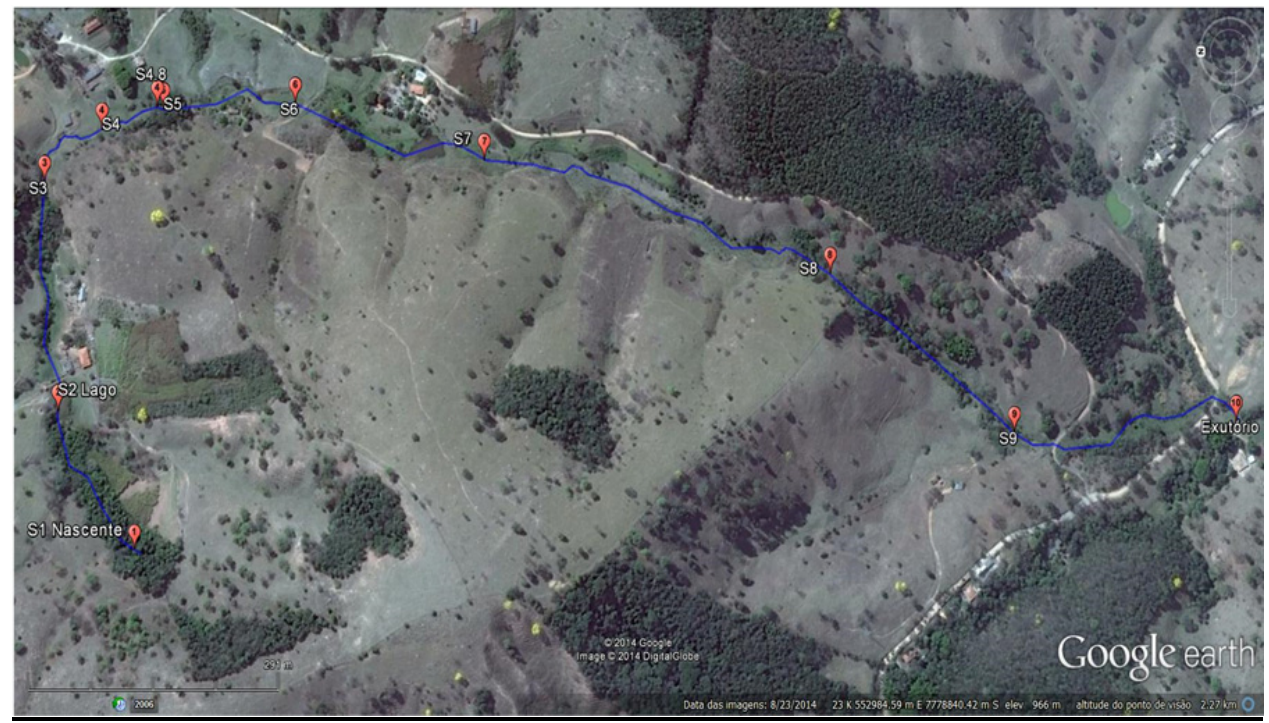

Figure 3. Location of the sampling points: first campaign 


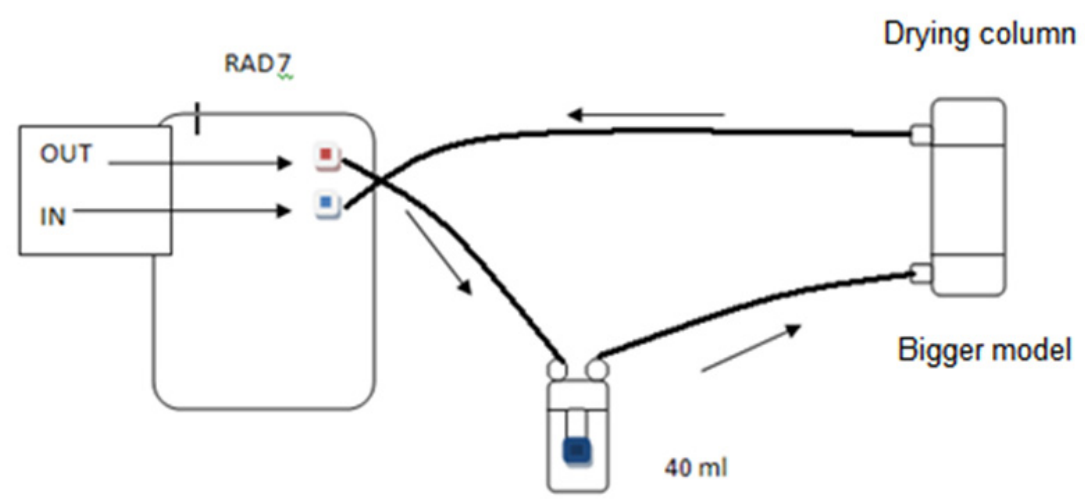

Figure 4. Drying process

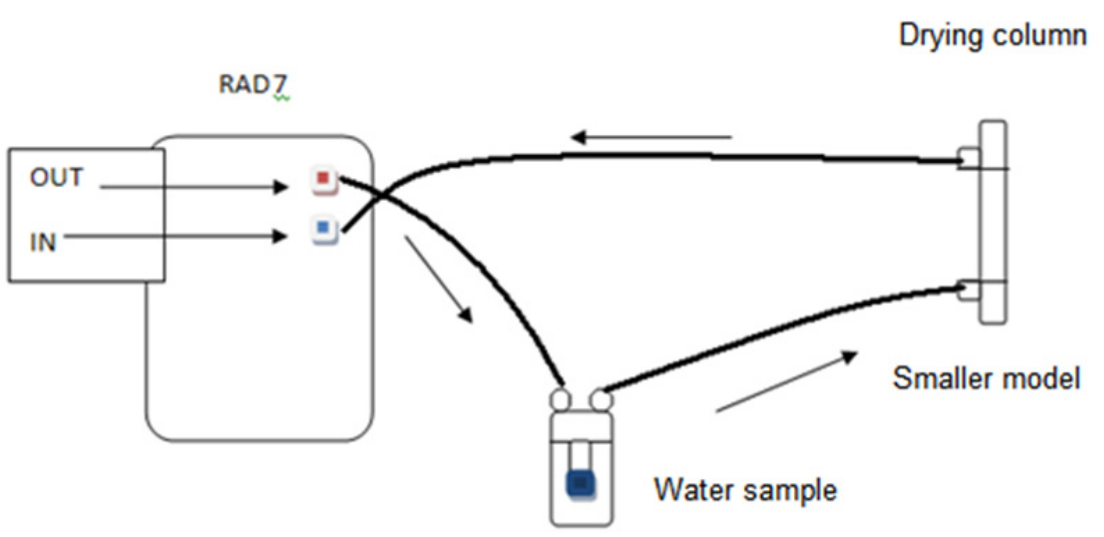

Figure 5. Analysis process

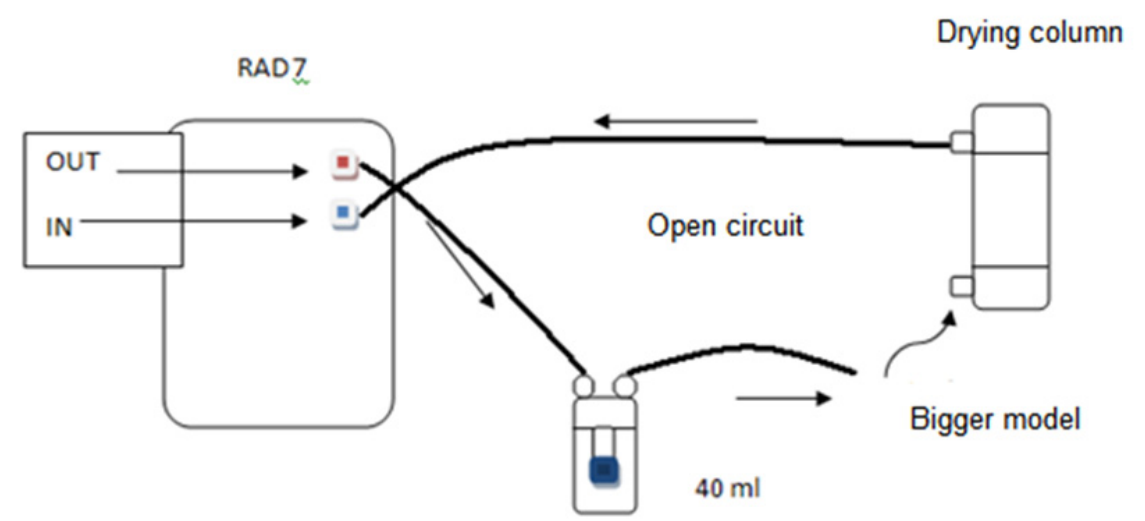

Figure 6. Cleaning process

The water of the stream was collected with the aid of hypodermic syringes with a small hose adapted along the bed of the stream, being subsequently transferred to flasks of $250 \mathrm{ml}$ capacity, suitably identified. The process should be done slowly to avoid the presence of air bubbles, which would compromise the results.

The RAD 7 makes four analyzes per sample and provides at the end, the mean value of the radon concentration and its standard deviation. The initial concentration of radon is obtained according to equation 1.

$$
A_{0}=A(t) * e^{t^{* \lambda}}
$$

where $A(t)=$ concentration of ${ }^{222} R n$ measured at time $t$;

$A_{0}=$ initial concentration of radon in the sample; 
$\lambda=$ decay constant of ${ }^{222} R n(=0.18)$;

$t=$ time between collecting and reading.

A second field campaign was conducted in November/2014, and this time more measurements were done, many of them between the same points where the first campaign was executed to do a better scan at the study area, trying to locate regions of possible discharges. In some cases, sampling points were chosen very close to the previous ones, just to obtain new results at these points.

Based on the results of the two first campaigns, two sections were chosen in order to scan the stretches aiming to verify the radon readings. The chosen sections correspond to those ones where bigger concentrations of radon were found in the preliminary studies. However, instead of using syringes to collect the water, a small peristaltic bomb was used at third campaign. Figure 7 shows a schematic of the sampling points (campaigns number 1 and 2).

At the third campaign (February 2015), section number 1 corresponds to the region between points 1.2 and 2.5, and section number two to the sector between points 1.5 and 2.7. It is valid to observe that in all procedures the water was collected very close to the bottom of the stream. At the third campaign, after the sampling procedures, a flow measurement was done at the beginning of both sections with the help of the Flow Tracker. The Sontek Flow Tracker (C) is a hand held ADV (Acoustic Doppler Velocimeter) that uses bistatic (separate transmitting and receiving) transducers to estimate either 2 or 3 dimensional flow in a $0.25 \mathrm{cc}$ sample volume located $10 \mathrm{~cm}$ from the probe. A transmitting transducer sends out a pulse to the sample volume and the acoustic signal is reflected back by particles suspended in the water to the receiving transducers. The Flow Tracker measures velocities with a range as low as $0.001 \mathrm{~m} / \mathrm{s}(0.003 \mathrm{ft} / \mathrm{s})$ and up to $4.0 \mathrm{~m} / \mathrm{s}(13 \mathrm{ft} / \mathrm{s})$. At this study the Flow Tracker was combined with a wading rod to measure the total discharge across the stream section.

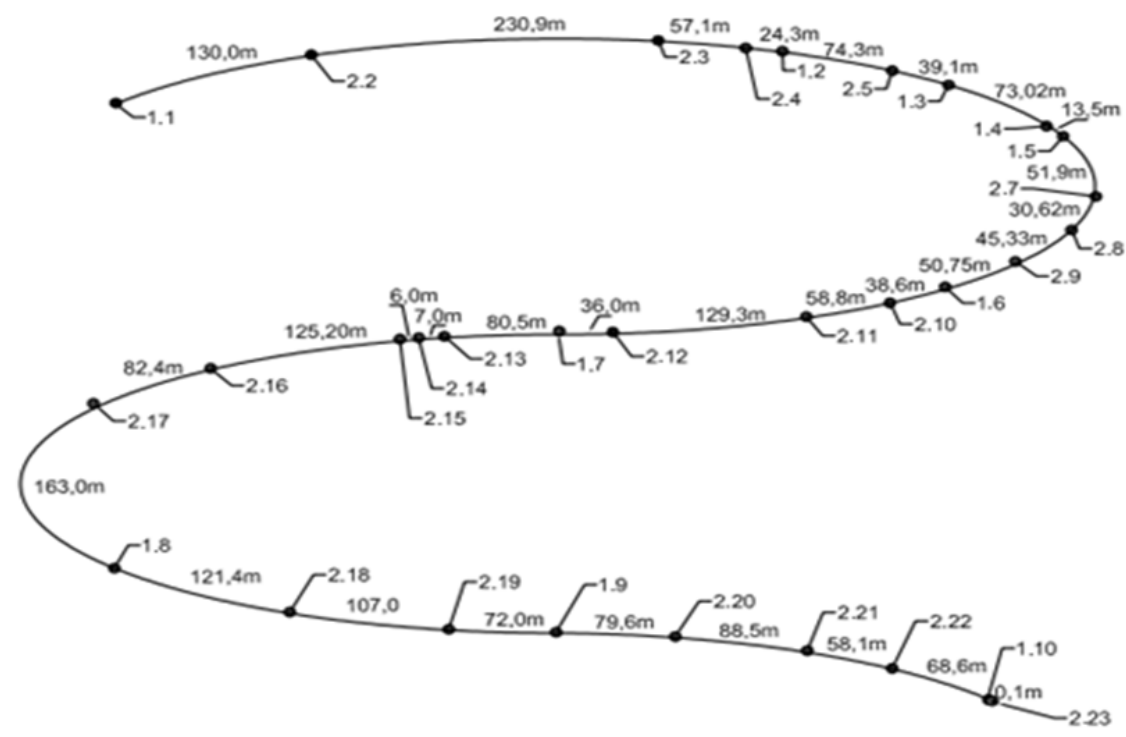

Figure 7. Location/distance of the sampling points at the first two campaigns

\section{Results}

Tables 1 and 2 show the results of the first two campaigns done to perform the radon measurements.

Table 1. Radon concentration: first campaign (September/2014)

\begin{tabular}{llllll}
\hline & $\begin{array}{l}\text { Radon concentration } \\
\text { and } S D \mathrm{kBq} / \mathrm{m}^{3}\end{array}$ & $\begin{array}{l}\text { Time and date of } \\
\text { the sampling }\end{array}$ & $\begin{array}{l}\text { Time and date of } \\
\text { the reading }\end{array}$ & $\begin{array}{l}\text { Time between } \\
\text { sampling and reading }\end{array}$ & $\begin{array}{l}\text { Radon concentration after } \\
\text { corrections and } S D \mathrm{kBq} / \mathrm{m}^{3}\end{array}$ \\
\hline 1.1 & $7.1 \pm 2.3$ & $9 / 16 / 2014$ & $9 / 16 / 2014$ & 0.1632 & $7.31 \pm 2.37$ \\
& & $16: 05$ & $20: 00$ & & \\
1.2 & $33.9 \pm 4.7$ & $9 / 16 / 2014$ & $9 / 16 / 2014$ & 0.1910 & $35.09 \pm 4.86$ \\
\hline
\end{tabular}




\begin{tabular}{|c|c|c|c|c|c|}
\hline & & $16: 55$ & $21: 30$ & & \\
\hline \multirow[t]{2}{*}{1.3} & $9.03 \pm 2.58$ & $9 / 16 / 2014$ & $9 / 16 / 2014$ & 0.2014 & $9.36 \pm 2.68$ \\
\hline & & $17: 10$ & $22: 00$ & & \\
\hline \multirow[t]{2}{*}{1.4} & $25 \pm 4.09$ & $9 / 17 / 2014$ & $9 / 17 / 2014$ & 0.3090 & $26.43 \pm 4.32$ \\
\hline & & $11: 05$ & $18: 30$ & & \\
\hline \multirow[t]{2}{*}{1.5} & $31.1 \pm 4.55$ & $9 / 17 / 2014$ & $9 / 17 / 2014$ & 0.3472 & $33.11 \pm 4.84$ \\
\hline & & $10: 40$ & $19: 00$ & & \\
\hline \multirow[t]{2}{*}{1.6} & $10.4 \pm 0.91$ & $9 / 17 / 2014$ & $9 / 18 / 2014$ & 0.9667 & $12.38 \pm 1.08$ \\
\hline & & $11: 20$ & $10: 32$ & & \\
\hline \multirow[t]{2}{*}{1.7} & $5.98 \pm 0.46$ & $9 / 17 / 2014$ & $9 / 18 / 2014$ & 0.9771 & $7.13 \pm 0.55$ \\
\hline & & $11: 45$ & $11: 12$ & & \\
\hline \multirow[t]{2}{*}{1.8} & $4.62 \pm 0.56$ & $9 / 17 / 2014$ & $9 / 18 / 2014$ & 0.9958 & $5.53 \pm 0.67$ \\
\hline & & $12: 00$ & $11: 54$ & & \\
\hline \multirow[t]{2}{*}{1.9} & $7.93 \pm 1.15$ & $9 / 17 / 2014$ & $9 / 18 / 2014$ & 1.0035 & $9.50 \pm 1.38$ \\
\hline & & $12: 30$ & $12: 35$ & & \\
\hline \multirow[t]{2}{*}{1.10} & $0.75 \pm 0.21$ & $9 / 17 / 2014$ & $9 / 18 / 2014$ & 1.0388 & $0.9 \pm 0.25$ \\
\hline & & $12: 50$ & $13: 46$ & & \\
\hline
\end{tabular}

Table 2. Radon concentration: second campaign (November/2014)

\begin{tabular}{|c|c|c|c|c|c|}
\hline Point & $\begin{array}{l}\text { Radon concentration } \\
\text { and } S D \mathrm{kBq} / \mathrm{m}^{3}\end{array}$ & $\begin{array}{l}\text { Time and date of the } \\
\text { sampling }\end{array}$ & $\begin{array}{l}\text { Time and date of } \\
\text { the reading }\end{array}$ & $\begin{array}{l}\text { Time between } \\
\text { sampling and reading }\end{array}$ & $\begin{array}{l}\text { Radon concentration after } \\
\text { corrections and } S D \mathrm{kBq} / \mathrm{m}^{3}\end{array}$ \\
\hline 2.1 & $6.58 \pm 1.62$ & $\begin{array}{l}11 / 18 / 2014 \\
14: 07\end{array}$ & $\begin{array}{l}11 / 18 / 2014 \\
19: 05\end{array}$ & 0.2069 & $6.83 \pm 1.68$ \\
\hline 2.2 & $41.23 \pm 2.47$ & $\begin{array}{l}11 / 18 / 2014 \\
14: 36\end{array}$ & $\begin{array}{l}11 / 18 / 2014 \\
20: 38\end{array}$ & 0.2514 & $43.14 \pm 2.58$ \\
\hline 2.3 & $73.43 \pm 6.07$ & $\begin{array}{l}11 / 18 / 2014 \\
15: 05\end{array}$ & $\begin{array}{l}11 / 18 / 2014 \\
21: 21\end{array}$ & 0.2611 & $76.96 \pm 6.36$ \\
\hline 2.4 & $45.88 \pm 3.89$ & $\begin{array}{l}11 / 18 / 2014 \\
15: 20\end{array}$ & $\begin{array}{l}11 / 18 / 2014 \\
21: 52\end{array}$ & 0.2722 & $48.18 \pm 4.09$ \\
\hline 2.5 & $12.18 \pm 1.39$ & $\begin{array}{l}11 / 18 / 2014 \\
15: 40\end{array}$ & $\begin{array}{l}11 / 19 / 2014 \\
14: 08\end{array}$ & 0.9361 & $14.42 \pm 1.65$ \\
\hline 2.6 & $5.64 \pm 1.23$ & $\begin{array}{l}11 / 18 / 2014 \\
15: 55\end{array}$ & $\begin{array}{l}11 / 19 / 2014 \\
07: 24\end{array}$ & 0.6451 & $6.33 \pm 1.38$ \\
\hline 2.7 & $50.1 \pm 4.58$ & $\begin{array}{l}\text { 11/19/2014 } \\
09: 38\end{array}$ & $\begin{array}{l}11 / 19 / 2014 \\
15: 16\end{array}$ & 0.2347 & $52.26 \pm 4.78$ \\
\hline 2.8 & $21.28 \pm 1.86$ & $\begin{array}{l}\text { 11/19/2014 } \\
09: 45\end{array}$ & $\begin{array}{l}11 / 19 / 2014 \\
14: 36\end{array}$ & 0.2021 & $22.07 \pm 1.93$ \\
\hline 2.9 & $44.05 \pm 3.43$ & $\begin{array}{l}11 / 19 / 2014 \\
10: 11\end{array}$ & $\begin{array}{l}11 / 19 / 2014 \\
16: 10\end{array}$ & 0.2493 & $46.07 \pm 3.59$ \\
\hline 2.10 & $15.45 \pm 2.88$ & $\begin{array}{l}11 / 19 / 2014 \\
10: 37\end{array}$ & $\begin{array}{l}11 / 19 / 2014 \\
16: 55\end{array}$ & 0.2625 & $16.20 \pm 3.02$ \\
\hline 2.11 & $10.94 \pm 1.21$ & $\begin{array}{l}11 / 19 / 2014 \\
10: 54\end{array}$ & $\begin{array}{l}11 / 19 / 2014 \\
17: 33\end{array}$ & 0.2771 & $11.50 \pm 1.27$ \\
\hline 2.12 & $1.9 \pm 0.3$ & $\begin{array}{l}11 / 19 / 2014 \\
11: 16\end{array}$ & $\begin{array}{l}11 / 19 / 2014 \\
18: 11\end{array}$ & 0.2882 & $2.00 \pm 0.32$ \\
\hline 2.13 & $36.8 \pm 2.82$ & 11/20/2014 09:29 & $\begin{array}{l}11 / 20 / 2014 \\
14: 50\end{array}$ & 0.2229 & $38.31 \pm 2.94$ \\
\hline 2.14 & $41.48 \pm 1.64$ & $\begin{array}{l}11 / 19 / 2014 \\
15: 40\end{array}$ & $\begin{array}{l}11 / 19 / 2014 \\
19: 14\end{array}$ & 0.1486 & $42.60 \pm 1.68$ \\
\hline 2.15 & $26.18 \pm 1.82$ & $\begin{array}{l}11 / 20 / 2014 \\
09: 36\end{array}$ & $\begin{array}{l}11 / 20 / 2014 \\
16: 20\end{array}$ & 0.2806 & $27.54 \pm 1.91$ \\
\hline 2.16 & $12.73 \pm 0.51$ & $\begin{array}{l}11 / 19 / 2014 \\
16: 00\end{array}$ & $\begin{array}{l}11 / 19 / 2014 \\
19: 53\end{array}$ & 0.1618 & $13.11 \pm 0.53$ \\
\hline 2.17 & $8 \pm 0.76$ & $11 / 19 / 2014$ & $11 / 19 / 2014$ & 0.1736 & $8.25 \pm 0.78$ \\
\hline
\end{tabular}




\begin{tabular}{|c|c|c|c|c|c|}
\hline & & $16: 23$ & $20: 33$ & & \\
\hline \multirow[t]{2}{*}{2.18} & $0.5 \pm 0.3$ & $11 / 19 / 2014$ & $11 / 19 / 2014$ & 0.1743 & $0.52 \pm 0.31$ \\
\hline & & $17: 00$ & $21: 11$ & & \\
\hline \multirow[t]{2}{*}{2.19} & $4.56 \pm 0.51$ & $11 / 19 / 2014$ & $11 / 19 / 2014$ & 0.1889 & $4.72 \pm 0.53$ \\
\hline & & $17: 21$ & $21: 53$ & & \\
\hline \multirow[t]{2}{*}{2.20} & $13.05 \pm 0.31$ & $11 / 20 / 2014$ & $11 / 20 / 2014$ & 0.2979 & $13.77 \pm 0.33$ \\
\hline & & $09: 55$ & $17: 04$ & & \\
\hline \multirow[t]{2}{*}{2.21} & $4.96 \pm 0.96$ & $11 / 20 / 2014$ & $11 / 21 / 2014$ & 0.8931 & $5.83 \pm 1.13$ \\
\hline & & $10: 14$ & $07: 40$ & & \\
\hline \multirow[t]{2}{*}{2.22} & $1.71 \pm 0.63$ & $11 / 20 / 2014$ & $11 / 21 / 2014$ & 0.9215 & $2.02 \pm 0.74$ \\
\hline & & $10: 14$ & $08: 21$ & & \\
\hline \multirow[t]{2}{*}{2.23} & $1.11 \pm 0.25$ & $11 / 20 / 2014$ & $11 / 21 / 2014$ & 0.9854 & $1.33 \pm 0.30$ \\
\hline & & $10: 25$ & $10: 04$ & & \\
\hline
\end{tabular}

Tables 3 and 4 show the results of the third campaign, done at the sections with the biggest values of radon previously found.

Table 3. Radon concentration: third campaign - section 1 (February/2015)

\begin{tabular}{|c|c|c|c|c|c|}
\hline Point & $\begin{array}{l}\text { Radon concentration } \\
\text { and } S D \mathrm{kBq} / \mathrm{m}^{3}\end{array}$ & $\begin{array}{l}\text { Time and date of the } \\
\text { sampling }\end{array}$ & $\begin{array}{l}\text { Time and date of } \\
\text { the reading }\end{array}$ & $\begin{array}{l}\text { Distance between } \\
\text { sampling points }\end{array}$ & $\begin{array}{l}\text { Radon concentration after } \\
\text { corrections and } S D \mathrm{kBq} / \mathrm{m}^{3}\end{array}$ \\
\hline 3.1 & $34.5 \pm 2.24$ & $\begin{array}{l}02 / 11 / 2015 \\
10: 40\end{array}$ & $\begin{array}{l}02 / 13 / 2015 \\
10: 10\end{array}$ & - & $49.27 \pm 3.20$ \\
\hline 3.2 & $40.35 \pm 0.63$ & $\begin{array}{l}02 / 11 / 2015 \\
10: 50\end{array}$ & $\begin{array}{l}02 / 13 / 2015 \\
10: 55\end{array}$ & 4.9 & $57.88 \pm 0.9$ \\
\hline 3.3 & $21.85 \pm 2.93$ & $\begin{array}{l}02 / 11 / 2015 \\
11: 15\end{array}$ & $\begin{array}{l}02 / 13 / 2015 \\
11: 45\end{array}$ & 15.0 & $31.44 \pm 4.22$ \\
\hline 3.4 & $19.65 \pm 2.19$ & $\begin{array}{l}02 / 11 / 2015 \\
11: 30\end{array}$ & $\begin{array}{l}02 / 13 / 2015 \\
12: 45\end{array}$ & 10.0 & $28.43 \pm 3.17$ \\
\hline 3.5 & $19.12 \pm 1.68$ & $\begin{array}{l}02 / 11 / 2015 \\
11: 45\end{array}$ & $\begin{array}{l}02 / 13 / 2015 \\
13: 45\end{array}$ & 10.0 & $27.82 \pm 2.44$ \\
\hline 3.6 & $18.37 \pm 1.91$ & $\begin{array}{l}02 / 11 / 2015 \\
11: 55\end{array}$ & $\begin{array}{l}02 / 13 / 2015 \\
14: 30\end{array}$ & 10.0 & $26.85 \pm 2.79$ \\
\hline 3.7 & $24.27 \pm 1.01$ & $\begin{array}{l}02 / 11 / 2015 \\
12: 10\end{array}$ & $\begin{array}{l}02 / 13 / 2015 \\
15: 15\end{array}$ & 10.0 & $35.6 \pm 1.48$ \\
\hline 3.8 & $19.37 \pm 0.76$ & $\begin{array}{l}02 / 11 / 2015 \\
12: 20\end{array}$ & $\begin{array}{l}02 / 13 / 2015 \\
16: 05\end{array}$ & 10.0 & $28.56 \pm 1.12$ \\
\hline 3.9 & $24.22 \pm 2.07$ & $\begin{array}{l}02 / 11 / 2015 \\
12: 30\end{array}$ & $\begin{array}{l}02 / 13 / 2015 \\
16: 50\end{array}$ & 10.0 & $35.87 \pm 3.07$ \\
\hline 3.10 & $14.77 \pm 2.13$ & $\begin{array}{l}02 / 11 / 2015 \\
12: 43\end{array}$ & $\begin{array}{l}02 / 13 / 2015 \\
17: 45\end{array}$ & 13.0 & $21.99 \pm 3.17$ \\
\hline 3.11 & $12.80 \pm 0.93$ & $\begin{array}{l}02 / 11 / 2015 \\
12: 50\end{array}$ & $\begin{array}{l}02 / 13 / 2015 \\
18: 30\end{array}$ & 10.0 & $19.14 \pm 1.39$ \\
\hline 3.12 & $14.12 \pm 0.54$ & $\begin{array}{l}02 / 11 / 2015 \\
13: 05\end{array}$ & $\begin{array}{l}02 / 13 / 2015 \\
19: 25\end{array}$ & 10.0 & $21.22 \pm 0.81$ \\
\hline
\end{tabular}

Table 4. Radon concentration: third campaign - section 2 (February/2015)

\begin{tabular}{|c|c|c|c|c|c|}
\hline Point & $\begin{array}{l}\text { Radon } \\
\text { concentration and } \\
S D \mathrm{kBq} / \mathrm{m}^{3}\end{array}$ & $\begin{array}{l}\text { Time and date } \\
\text { of the sampling }\end{array}$ & $\begin{array}{l}\text { Time and date } \\
\text { of the reading }\end{array}$ & $\begin{array}{l}\text { Distance } \\
\text { between } \\
\text { sampling points }\end{array}$ & $\begin{array}{l}\text { Radon concentration } \\
\text { after corrections and } S D \\
\mathrm{kBq} / \mathrm{m}^{3}\end{array}$ \\
\hline 3.13 & $34.87 \pm 3.56$ & $\begin{array}{l}02 / 10 / 2015 \\
14: 40\end{array}$ & $\begin{array}{l}02 / 10 / 2015 \\
18: 35\end{array}$ & - & $35.91 \pm 3.67$ \\
\hline 3.14 & $50.22 \pm 4.69$ & $\begin{array}{l}02 / 10 / 2015 \\
14: 55\end{array}$ & $\begin{array}{l}02 / 10 / 2015 \\
21: 07\end{array}$ & 5.0 & $52.61 \pm 4.91$ \\
\hline
\end{tabular}




\begin{tabular}{llllll}
\hline 3.15 & $33.22 \pm 1.79$ & $02 / 10 / 2015$ & $02 / 10 / 2015$ & 5.0 & $34.30 \pm 1.85$ \\
& & $15: 00$ & $19: 15$ & & \\
3.16 & $67.52 \pm 4.83$ & $02 / 10 / 2015$ & $02 / 10 / 2015$ & 6.0 & $71.11 \pm 5.09$ \\
& & $15: 06$ & $22: 00$ & & \\
3.17 & $11.22 \pm 0.73$ & $02 / 10 / 2015$ & $02 / 12 / 2015$ & 5.0 & $15.75 \pm 1.03$ \\
& & $15: 30$ & $12: 45$ & & \\
3.18 & $13.87 \pm 0.88$ & $02 / 10 / 2015$ & $02 / 12 / 2015$ & 5.0 & $20.18 \pm 1.28$ \\
& & $15: 45$ & $17: 43$ & & \\
3.19 & $19.52 \pm 0.53$ & $02 / 10 / 2015$ & $02 / 12 / 2015$ & 5.0 & $28.73 \pm 0.78$ \\
& & $15: 55$ & $19: 25$ & & \\
\hline
\end{tabular}

It is possible to see that at campaign 1, the biggest value is 35 times bigger than the smallest one. At campaign 2, this difference became much bigger and achieves 150 times. The results from campaign 3 show that at section 1 the peak value is 3 times bigger than the smallest one, and at section 2 the peak is 4.7 times bigger.

Figure 8 presents the concentrations of radon measured considering the distance from the source of the stream, with the results of all the campaigns. The two peaks of the graph correspond to the studied sections at the third campaign.

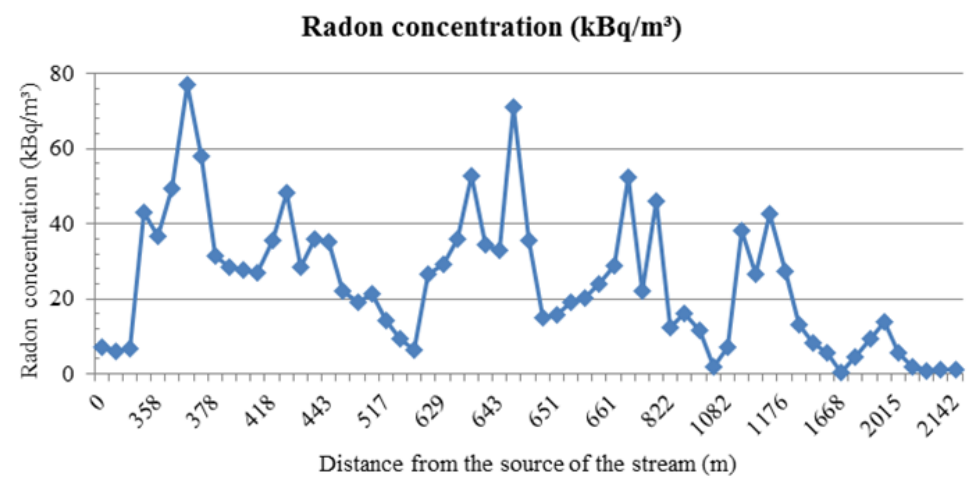

Figure 8. Radon concentration as a function of the distance of the source

A statistical analysis was done considering all the measurements previously presented, with the help of the MINITAB 16 software. Figures 9 to 12 show the obtained results.

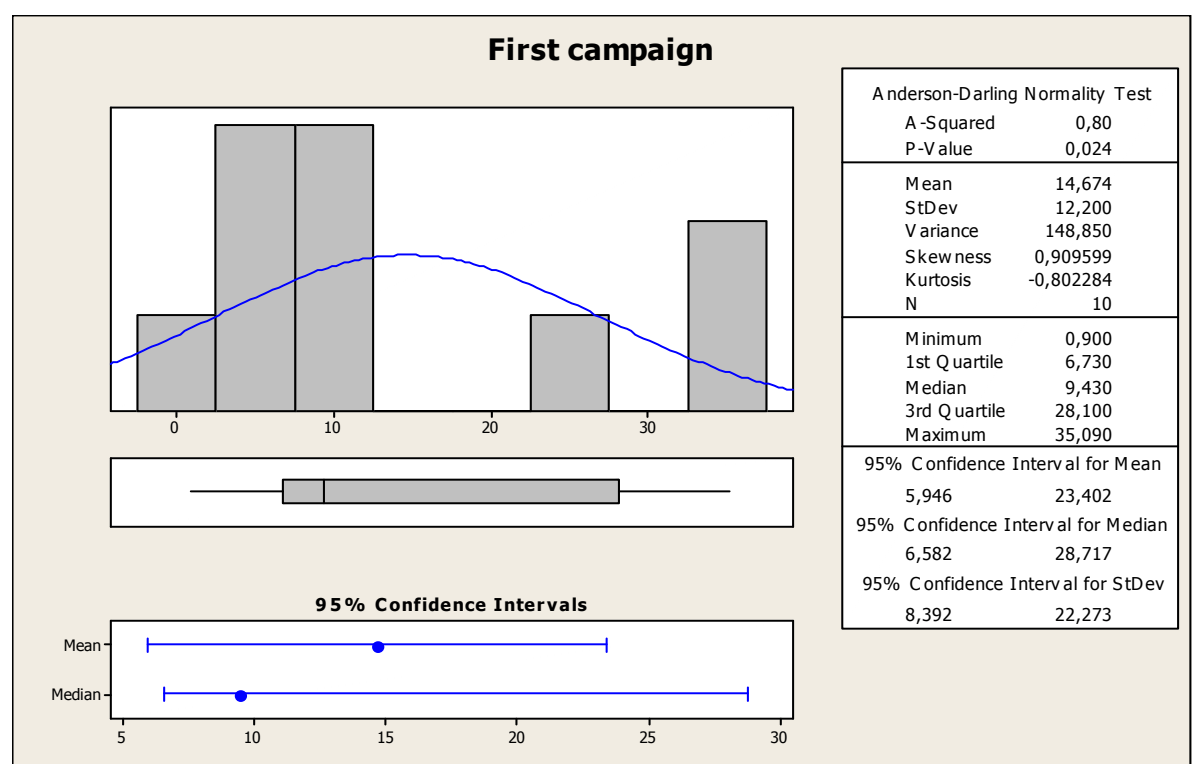

Figure 9. Statistical analysis: first campaign 


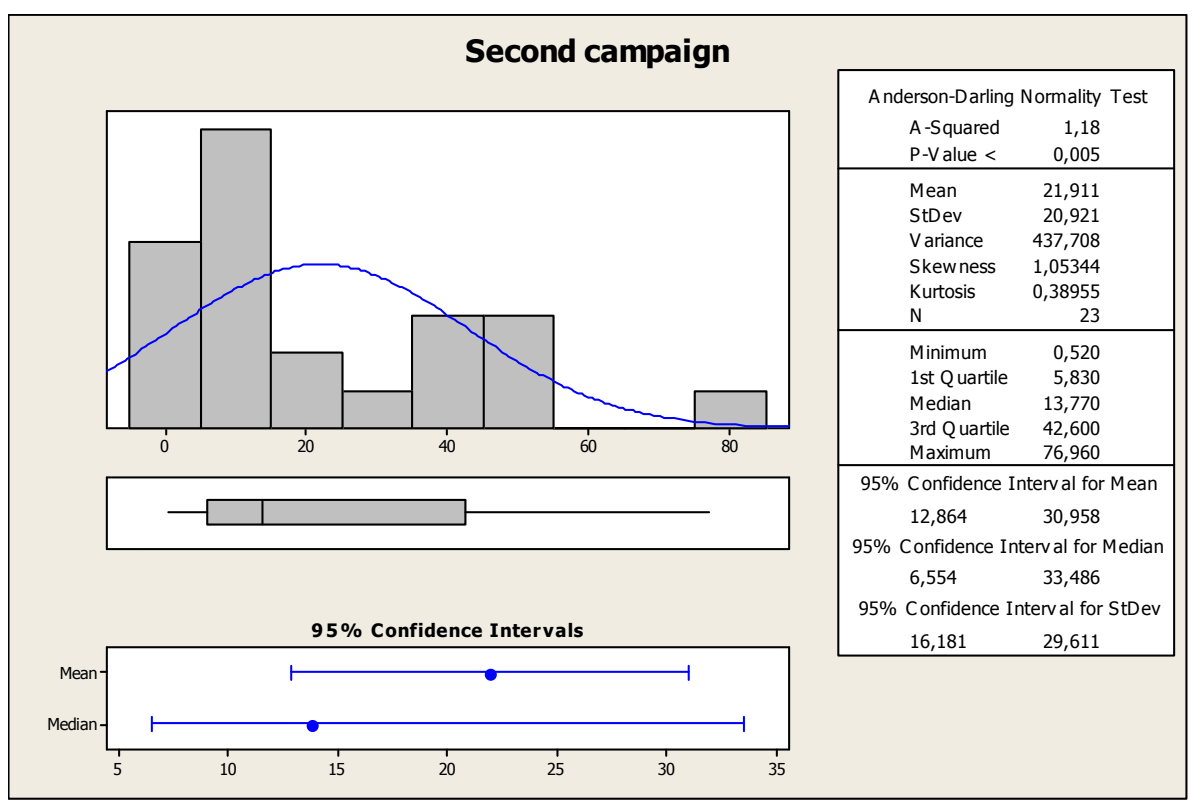

Figure 10. Statistical analysis: second campaign

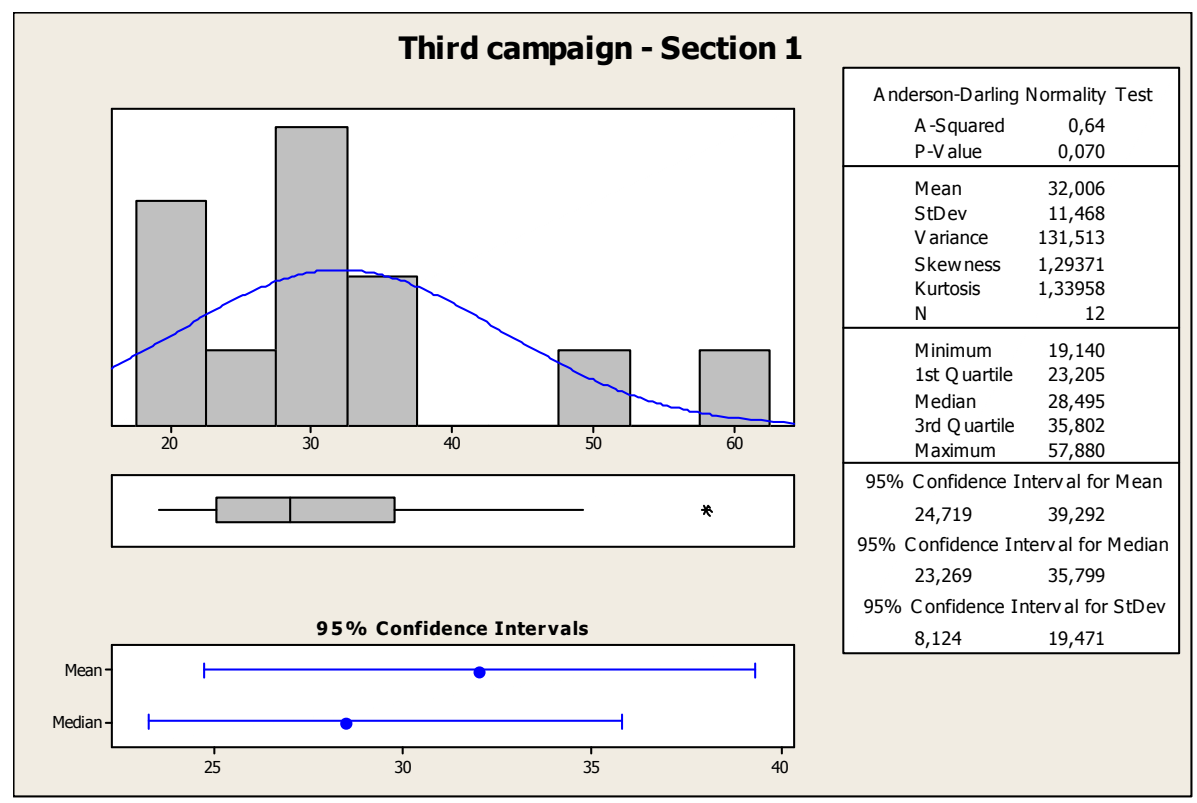

Figure 11. Statistical analysis: third campaign/section 1

Analyzing the results it is possible to verify that the mean values of the radon concentration from the first two campaigns (14.64 and 21.91) are smaller than the ones from the third campaign (32.00 and 36.94). Also, the two first minimum values (0.52 and 0.90) are much smaller than the ones from third campaign (15.75 and 19.14). All these facts indicate that the samples from the third campaigns were collected at discharge zones.

It is also possible to see that only the maximum value from third campaign/section 1 (57.88) was considered as an outlier. 


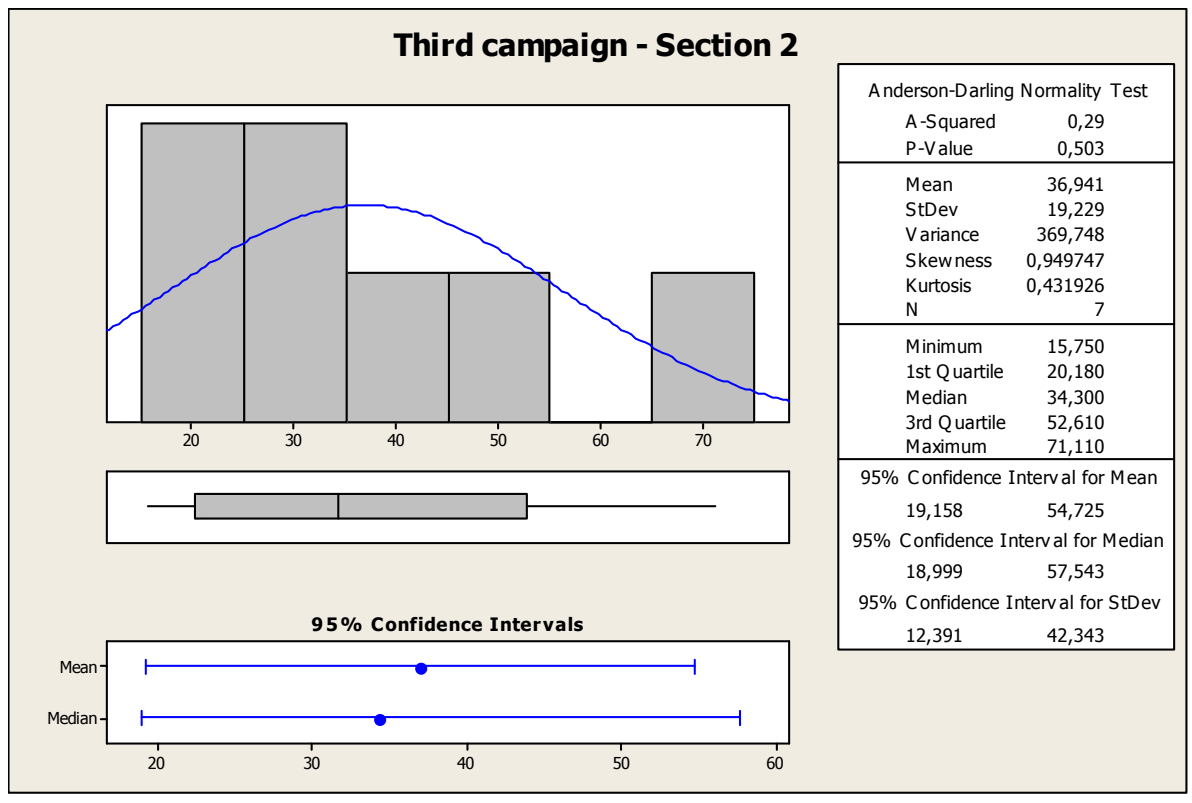

Figure 12. Statistical analysis: third campaign/section 2

Table 5 shows the results of the natural flows of the stream, obtained with the help of the Flow Tracker. It is possible to see the increase of the flow in the region under study. Again the results indicate that at this region occurs a connection between underground and surface waters, due to the growth of the flow. The distance between the two sections is approximately 300 meters.

Table 5. Natural flows of the stream

\begin{tabular}{lc}
\hline Section (upstream) & Natural flow (liter/second) \\
\hline Section 1 & 2.7 \\
Section 2 & 3.6 \\
\hline
\end{tabular}

It is valid to observe that due to some technical reasons it was not possible to consider the results obtained by the fluorimeter (GGUN-FL30) in order to measure the natural flows downstream both sections with the help of fluorescent tracers. The operations done in order to collect the water samples for measuring radon increased the value of the turbidity of the water course, which compromised the GGUN results. It is expected that at next campaign this equipment will be used (two more field campaigns should be done at 2015) before collecting the water samples.

\section{Conclusions}

The use of radon as a tracer to locate discharge sections at Juatuba basin was able to identify sections where its concentration showed significant values, what means the existence an underground water discharge in the sector under study. The maximum concentration of radon measured was about 150 times higher than the minimum, considering the results of the first two campaigns. The third campaign, done at the two sections where the concentration of radon showed the biggest values, found numbers greater than the first ones, what indicates the presence of a discharge zone. The difference between the flows is another factor that indicates this possibility.

This connection between surface and underground water is vital for maintaining the water level in the study area, due to the absence of rains at Juatuba during this past year. Also, the RAD 7 equipment proved to be adequate for the work associated with the project.

At the next campaigns the fluorimeter will be used to measure the flows at the beginning and at the end of both sections under study. A small amount of a fluorescent tracer (rhodamine or fluoresceine) will be injected, and it is expected to verify the growth of the flows in the studied sections. This will be another evidence of the relation between the presence of radon in water and the existence of a discharge zone. 


\section{Acknowledgements}

The authors would like to thank the FAPEMIG for the support to the development of this research. We also thank Mr. Carlos Alberto Carvalho Filho for his help to analyze the data.

\section{References}

Burnett, W. C., \& Dulaiova, H. (2003). Estimating the dynamics of groundwater input into the coastal zone via continuous radon-222 measurements. Journal of Hydrology, 69(1-2), 21-35. http://dx.doi.org/10.1016/S0265-931X(03)00084-5

Burnett, W. C., Peterson, R., Moore, W. S., \& Oliveira, J. (2008). Radon and radium isotopes as tracer of submarine groundwater discharge - Results from the Ubatuba, Brazil SGD assessment intercomparison. Estuarine, Coastal and Shelf Science, 76(3), 501-511. http://dx.doi.org/10.1016/j.ecss.2007.07.027

Chanyotha, S., Burnett, W. C., Taniguchi, M., Kritsananuwat, R., \& Sriploy, P. (2010). Experience in using radon and thoron data to solve environmental and water problems. Radiation Protection Dosimetry, 141(4), 374-378. http://dx.doi.org/10.1093/rpd/ncq225

Cook, P. G., Favreau, G., Dighton, J. C., \& Tickell, S. (2003). Determining natural groundwater influx to a tropical river using radon, chlorofluorocarbons and ionic environmental tracers. Journal of Hydrology, 277 (1-2), 74-88. http://dx.doi.org/10.1016/S0022-1694(03)00087-8

Davis, S. N., Thompson, G. M., Bentley, H. W., \& Stiles, G. (1980). Ground-water tracers - a short review. Ground Water, 18(1), 14-23. Retrieved from http://info.ngwa.org/gwol/pdf/800601201.PDF

DURRIGDE RADON INSTRUMENTATION (2015). RAD7 Radon Manual. Durridge Company. Revision 7.3.2.

Freyer, K., Treutler, H. C., Dehnert, J., \& Nestler, W. (1997). Determination of ${ }^{222} \mathrm{Rn}$ in groundwater - recent applications for the investigation of river bank infiltration. Proceedings of Second International Conference on Isotopes. Sydney, Australia. Retrieved from http://www.iaea.org/inis/collection/NCLCollectionStore/_Public/29/057/29057249.pdf

Giap, T. V. (2003). Use of radon-222 as tracer to estimate groundwater infiltration velocity in a river bank area. Nuclear Science and Technology, 2(2), 12-17. Retrieved from http:/www.vinatom.gov.vn/Userfiles/image/giang_10/02TVGIAP.pdf

Low, R. (1996). Radon as a natural groundwater tracer in the Chalk aquifer, UK. Environmental International, 22 (1), S333-S338. http://dx.doi.org/10.1016/S0160-4120(96)00127-4

Silva, L. L., Donnici, C. L., Ayala, J. D., Freitas, C. H., Moreira, R. M., \& Pinto, A. M. F. (2009). Traçadores: O uso de agentes químicos para estudos hidrológicos, ambientais, petroquímicos e biológicos. Química Nova, 32(6), 1576-1585. http://dx.doi.org/10.1590/S0100-40422009000600042

Singh, B. P., \& Kumar, B. (2005). Isotopes in Hydrology, Hydrogeology and Water Resources. Narosa Publishing House, India.

Swarzenski, P. W. (2007). U/Th series radionuclides as tracers of coastal groundwater. Chemical Reviews, 107 (2), 663-674. http://dx.doi.org/ 10.1021/cr0503761

\section{Copyrights}

Copyright for this article is retained by the author(s), with first publication rights granted to the journal. This is an open-access article distributed under the terms and conditions of the Creative Commons Attribution license (http://creativecommons.org/licenses/by/3.0/). 